\title{
THE QUEUING APPLICATION OF ANTI-CRUSADE CIVILIZATION IDENTITY ON NEWS BROADCAST POLICY OF ISLAMIC REPUBLIC OF IRAN BASED ON HUNTINGTON'S POINT OF VIEW
}

\author{
Ardeshir Zabolizadeh \\ Faculty Member of Communication and Media \\ Mohammad Dejkam \\ Master of Journalism
}

\begin{abstract}
In this paper, it is tried to investigate the identity distinction roots of Islamic world with other types of civilization identity based on the effects of crusade wars on the identity of Islamic identity, and analyze the historical memory of Islamic world about the issues of Israel and the west in this platform. Considering the stated platform of historical-identity conflict, it is tried to analyze the news policymaking of cross-border media of Islamic Republic of Iran broadcasting organization. In this paper, as an interdisciplinary research, it is tried to explain the effect of media and identity on international relationships by using political science, sociology, and communication science theories, and give an answer to the question that how does Islamic Republic advertise itself through the media and news using the historical memory of Muslims from crusader-ism of the west, and its anti-imperialist policy? Achieving this goal, the researcher tries to explain identity dimensions of a society by proposing a theoretical framework of identity and clarify the effects of identity on international relationship based on constructivism and clash of civilizations viewpoint. Then, by stating the quiddity of anti-crusade identity queuing from the viewpoint of Huntington, it is tried to outline this theory according to the historical memory of Muslims from the first widespread confrontation of the west wit Islamic world in crusade wars and explain the position of Iran in confronting the crusaders and how this capacity should be used in cross-border media productions of Iran.
\end{abstract}

Keywords: Crusade wars, Clash of civilizations, News, Broadcast, Historical memory, Identity

\section{INTRODUCTION}

The rise of Islamic world against west is due to the self-awareness that is acquired after colonization. In this self-awareness, Muslims define their selves using identity. In fact, on the one hand they define their identity and on the other hand, they express their boundaries with others. In these definitions of self and others, history has a special position. The roots of conflicts between the two civilizations go back to the beginnings of the advent of Islamic civilization. The quick development of Islam in the west was accompanied with numerous failures of the west civilization that were continued until the full conquest of Andulsia. The attempts of the west for compensation of these failures were started with crusade wars. These bicentenary wars inflicted Islamic world with great trauma. This was because, from one hand their holy grounds were confiscated, and on the other hand, these were the beginning attempts of the west in confronting with Islamic civilization. Therefore, the historical memory of crusade-activism of the west was turned to a symbol for actions against this civilization. This historical memory was intensified when the holy ground were taken from Islamic world and entrusted to some Jews. At that time, whenever an Islamic government took actions for confrontation with the Zionism, it turned into the champion of Islamic world. As one of the most serious distinctions of Islamic world with civilization of the west is the crusade-activism of the west and anti-crusade-activism of Islamic world, the governments opposing Israel turns into the champion of the fight against crusade, in the minds of Muslims around the world. By attracting these thoughts for this government, the probability of political development and increase of the 
acceptability of our ideology in Islamic world, would be made more possible. Currently, the most oppositions against Israel is by Islamic Republic of Iran; however, it is not considered as a Jihadi government against crusades, and with the opposing media attempts of Arabs and the west, it is known as the disruptive of stability in Islamic world. Therefore, the main struggle of this research is answering to the question that how can Islamic Republic of Iran, perform better media coverage of its foreign policy, using historical memory of Muslim and its own historical capacity?

In this research, it is assumed that expressing the historical position of Iran in opposition to the west, especially in middle ages, and also the effect of Iranian factors in confrontation with crusades can confirm the historical position of Iran in preserving Islamic world against in confronting the west, and by emphasis on the attempts of Iran against Zionism, present Iran as an Jihadi country against the crusades of today. To evaluate this hypothesis, first the theoretical framework regarding the issue of identity, the position of Identity in international relationships, and the Identity queuing in the present world, is discussed. Then, by explaining the position of crusade wars in the historical memory of Muslims, the method of using this capacity by the media of Islamic republic of Iran is explained.

\section{Theoretical framework of research method}

The word "Hoviat" in Persian or Arabic, meaning identity, originating from the word "Hova", meaning existence or being, nature, character, personality, ego, plays an unmatched and long-serving role in the personal and social lives of individuals up to a level that the answer to "who to be?" is the natural and integral need of humanity for introduction of "self" and its relation with "others". Identity is an interdisciplinary subject which is investigated from different points of view and it also includes different kinds and dimensions (Goodarzi, 1385: 17). The notion of the word "Hoviat" has been used with several different concepts such as the subjective and objective region, we, self, understanding of self, revealing self, awareness of self, self-image, self-identity, pattern, super pattern, character, and so on (Doran and Mohseni, 1383: 81).

"Hoviat" or identity as stated in the Oxford dictionary originates from the Latin word "identitas" which is derived from the word "idem" with the concept of same and identical (Oxford Dictionary,"identity", www.oxforddictinaries.com) and it has two main concepts: The first concept represent the notion of absolute similarity; this is similar with that. The second concept represents the notion of differentiation which assumes compatibility and continuity with passing of time. Therefore, identity creates two possible relations between individuals and objects simultaneously; on the one hand similarity and on the other hand difference (Jankins, 1381: 5). In the common view, identity is the border between "us" and "others" and a relative notion which simultaneously includes similarity and difference. This similarity and difference is discussed in different levels from family to extensive cultural identity. At any level, humans deal with the concept of self and others in order to set borders between self and others. Determination of similarities and differences are largely due to the interactions with others. In other words, identity is defined and determined for humans through their interaction with others (Goodarzi, 1385: 23). Likewise, the social systematic similarities and differences are the achievements of social identity. Actually, social identity, based on similarities and differences, divide social groups to us and others (Jikins, 1381: 9). George Herbert Mead, one of the most important theorists of social identity who the view of mutual symbolic action is indebted to him, on the social identity believes that each individual forms identity or his self through organizing other individuals' viewpoint in the form of organized social or group viewpoint. Basically, the image that the individual creates of himself is the reflection of others' thoughts that are ascribed to him (Turner, 2001: 12). Social identities include factors that confirm them. These factors are different in the view of different scientists and everyone develop them based on their own point of view. However, in summing up the ideas of these individuals, some certain factors can be achieved. Land, political unit, race, religion, and history can be considered the major factors of identity in time and location intervals. 
Each of the mentioned factors is separable and capable of being scrutinized. Identity is a personal or group sensation from self and the product of self-awareness, meaning that I or we have different characteristics. Actually, identity has two faces. A face which defines "who am I?" due to self-awareness and the other face which finds the difference between self and others by defining others and setting boundaries between self and others. Some scientists define identity as follows:

"Identity is related to the personal characteristics and distinction (self-centeredness) which is preserved and conducted by an actor and is formed due to the relation with others" (Jepperson, 1966: 59).

As long as individuals have mutual relations with each other, there will be no choice but to define self through their relation with others, and define their similarities and differences from others. There are some points that should be taken into consideration about identity. First, that both individuals and groups have identity; although, find themselves in groups and define self again. As it is shown by the social identity theory, the need for identity motivates individuals into search of identity in groups. It might be possible that an individual is a member of many groups and he/she might be able to alter identities. Second, identities have different levels and individuals, tantamount to their presence in any level, have both the concept of self and others. As a result, in any level of identity, it is possible that two groups have accepted different identities for themselves; however, in facing with other groups which are more different from them, again, they propose a new concept of self and others, and in this new concept, the previous distinctions are put aside and they unite against the new identity (Huntington, 2005: 25).

Self and others in identity, from the minor personal level up to the macro international level, affects the actions of individuals and societies. In constructivism theory of international relations, the first important factor of ontology is that intellectual and normative structures are as important as physical structures as systems are meaningful that they define how actors should interpret their physical environment. The second factor is identities which form the interests (Price and Reus-Smith, 1998: 266-67). Constructivist view point deals with the issue that how social identities and norms of people can develop among them with established relations. As the benefits rise upon social relations, not in analytical or previous forms, necessarily we can neither be optimistic nor pessimistic towards relative type of interactions between governments and cooperation or conflicts among them (Hadian, 1382: 919). Here, identity becomes a matter of importance. Identity, with a relatively constant concept, is based on specific role of self and expectations from others. Actors gain their identity and interests through participation in collective concepts -those concepts that define structures and organize actions. (Hamanja) With this point of view the concept of identity in societies can affect international relationships. In this view, which is to some extent different from new actual viewpoint, collective identity is considered a factor of political activism.

On this basis, identity has gained great importance in the political equations of the world. However, with the downturn of Soviet Union, identity has revealed itself in the greatest form in the international stage. This great form is civilization identity. In this concept which was first proposed by Samuel Huntington, new queuing of identity based on cultures of societies was proposed. In this point of view, common culture of civilizations develops new borders, and self and others are determined and divided based on civilization identity. Whenever these cultural identities overlap, civilization rifts are created which are followed with long-term bloodsheds that create universal queuing (Huntington, 1378: 38). This civilization is based on visual similarities such as language, history, religion, habits, and institutions, and also, intellectual factor of human self-knowledge (Haman: 63) in which these civilization similarities include different percent of effectiveness. For instance, the effect of religion in Western or Latin civilization is much lower than Islamic civilization; however, Islamic civilization, like Japanese civilization, is not based on a unit language.

"Enumerating the 8 main civilization of the world, Haman proposes that as Western civilization is currently the superior civilization of the world, some not-western societies try to make west as an

Submit Date: 01.05.2016, Acceptance Date: 20.06.2016, DOI NO: 10.7456/1060JSE/082

1137 Copyright $($ C) The Turkish Online Journal of Design, Art and Communication 
example and become the same or join it; however, Confucian and Islamic societies want to increase their economic and military power to withstand against west and reach equilibrium" (Haman: 29).

Islamic world is introduced as one of the most important challenges of western civilization at present time and future. This civilization, despite owning energy resources, strategic straits, and productive population, could not stabilize its position as Confucius and Orthodox societies have challenged and rivaled the west. Samuel Huntington considers the lack of unity in the Islamic world as the most important factor of its weakness. He highly considers identity in Islamic world a combination of religion and tribe. About this issue he states:

"Tribalism and religion plays a very important role in social, political, and economical changes of Arabic countries and their political system. These two factors so mixed that they are considered the most important factors and variables in determination of political culture and political mentality of Arabs. ... Of the reasons of success of the founder of Saudi Arabia is creation of union for different tribes. Furthermore, separation of religious identity into two groups of Shia and Sunni is one of the most important reasons of lack of unity in Islamic world."

Islamic world has gained this knowledge that it should stand against the west and establish its own civilization. This viewpoint is viewed in different parts of Islamic world. Imam Khomeini, as one of the pioneers of this thought and the symbol of awareness of Shia world, Al-Qaeda, and fundamentalism of Sunni for confronting west and strives of Turkey with Islamic parties such as justice and expansion seeking following re-establishment of Islamic empire, in all show the awareness of Islamic world for their re-rise. However, this rise is not possible with divisions of identity. This issue is partly due to the religious differences; however, in a pathological view of Islamic world in confronting the west, this is connected to the historical roots of identity distinctions which are mostly centered in crusade wars and expelling of Muslims from Spain. This view is acceptable by both west and Islamic world. The proof of this statement is in the distinction of west identity that they use in their confrontation against Muslims. After the incident of September the 11th, this crusade identity based distinction came into attention more than before ${ }^{1}$. The development of this distinction of identity among societies including Islamic or western is possible in the world based on media tools. In fact, this is the media that develop this identity.

In fact, it can be said that in the present world, for people, identity - Who am I and who the other is - is formed and becomes intrinsic by the media. The fact is that our perspective of the world is not a direct view. We don't have any experience about the occurrences in the remote corners of the earth nor we have any experience of the far areas of the sky; however, we become aware of different occurrences using the mass media productions. Not the news context any journalist, nor the cameras can represent an occurrence impartially. The person who determines the speed of filming, the size and type of lens, and the filming angle, intentionally or unintentionally represents a cut of reality and often a specific story in front of his camera. Therefore, audience understands phenomenon in the form of stories and reporter, as a human being and media practitioner, knows nothing but to narrate (Aminian and Teimourpour, 1391: 72).

This collection of stories - which are generally set according to demands of authorities and governmentsare the stories that form our knowledge of self and others. By dismantling, combining, and readjustment of details, a media connects separate occurrences and edits them in the form of a story. The collection of these series of stories forms our subjective thoughts or phantasm of the world surrounding us and creates mental images for contemporary men so that they could confront their surroundings and feel that they know their surroundings (Hamanja).

Research findings

Identity factors in the west and Islamic media

\footnotetext{
${ }^{1}$ For more information R.K. (Bull and Hously, 2003)

Submit Date: 01.05.2016, Acceptance Date: 20.06.2016, DOI NO: 10.7456/1060JSE/082 Copyright (C) The Turkish Online Journal of Design, Art and Communication
} 
In the current world, identity has gone beyond the borders of countries; therefore, national identity is not considered the final macro layer of identity, rather, this identity is a layer of minor and major identities which are defined in the civilization collection. In order to confront other identities, new identity adopts partners among those having similar cultures. Thus, there could be some distinctions of identity among nations; however, in this macro view, the distinctive factors are less considered and the emphasis is more on the affirmative aspects. In the civilizational identity queuing of the west, with many conflicts ${ }^{2}$ among its members, now with existence of many enemies -other nations- underlines the common aspects of identity and disregards the distinctions or does not express them highly. This is while in the history of tis civilization there was an intensive divergence of identity among its members due to race, religious, geographic, political and other reasons. Today, besides the military institutions and pacts ${ }^{3}$ that the west has established, for stabilizing its identity, cultural NATO by using media tools is included in its propaganda. In this regard, identity factors as the classic heritage of the west including cultures of Greek and Rome, Catholic and Protestant religion (West Christianity), European languages (Roman and German languages), separation of materialistic and spiritual power, ruling of law, social pluralism (classified pluralism), representative based institutions, and finally the individual belief form the macro-identity of the west (R.K. Huntington, 1378: 109-111). In these distinctions, there are no difference between Finnish and Spanish. These factors are comprehensive enough that they include all the history of west and its culture. Therefore, a coherent identity is formed in this civilization that confronts other potential damages from other civilizations. The presentation of these factors through west media, on the one hand, is due to coordination of values of other cultures with them, and on the other hand, for presentation of identity and a unity self to other members of this identity. In this view; although the first role British actor ${ }^{4}$ of the movie "Kingdom of heaven" is a French knight; however, a German, Spanish, or Norwegian consider him as his/her hero as he has fought against counter-west identity -the Muslims. There is a broad spectrum of activities including visual and written activities in this broad spectrum of media efforts. The book of "Hard Choices", though being the memories of an American politician, in the view of civilization, she is an idol who defends the west ideals such as democracy, human right, women right and so on.

Distinction dimensions of both Islamic and west identity are to some extent common. Crusade-activism and Reconquista of Spain are the similar dimensions of these two civilizations but only with some differences. Although Islamic worlds has come to understand its collision with west in vast geographies and in long-term, but finally it has come to this self-awareness that it should appeal to a re-rise; however, it lacks one of the most important factors of macro-identity: Unity. Minor identities in Islamic world are very powerful due to religious, racial, and historical reasons. These most powerful factors of minor cultures can be seen in the tribal context of Islamic world which has even influenced the national borders. From the Muslims of India and middle Asia, to the Islamic west in the north of Africa, the identity of self and society is defined mostly in tribal form. This issue is so powerful that tribes can turn into a pressing factor of pressured the government by uniting with their races in neighbor countries (R.K. Huntington, 1387: 278). This is a very familiar issue for the governments of Islamic world. Besides the issue of tribalism, faith or sect is another factor of segregation of macro-identity in Islamic world. In the most overall form of this segregation, the division of self-concept, in societies, into Shia and Sunni, is considered the greatest distinction aspect of sect and in more minor cases, inter-sect conflicts such as the conflicts of Sufis of Sunni with Wahhabi fundamentalism has caused identity distinctions. In some cases, both macro-identity aspects of distinctions combine with each other. This means that tribes, for more distinctive identity, select different sects so that they can strengthen their tribal identity. These religious

\footnotetext{
${ }^{2}$ The 20-year, 7-year, and 100-year battles of England and France during the tumultuous Middle Ages and incursions of German knights in eastern Europe, and also the great battles of kings during colonization and enlightenment era of 17 till 19 century, are of such wars stated in the context.

${ }^{3}$ Such as North Atlantic Treaty Organization (NATO)

${ }^{4}$ Orlando Jonathan Blanchard Bloom
}

Submit Date: 01.05.2016, Acceptance Date: 20.06.2016, DOI NO: 10.7456/1060JSE/082 Copyright $($ The Turkish Online Journal of Design, Art and Communication 
and tribal views in Islamic world are followed by numerous disadvantages. One of such disadvantages is the present intensification of the diplomatic conflict between Iran and Saudi Arabia. Besides the point that these conflicts have mostly originated from international issues; however, the racial distinction definition of Arab-Ajam, and religious distinction of Sunni-Shia, are reflections of identity rifts in Islamic world. These definitions are while there are much less bloodsheds and identity distinctions in historical memory of Islamic world in comparison to the European world.

In these identity distinctions, mostly, the historical roots -more for the legitimacy of the viewpoint- is considered. This is, to some extent, due to orientation; and valuation of in this science is specific to Arab world and Sunnis; and the imperfect and highly limited readings of history are specific to Shia and Iranians. Referring to the cultural history, those that Sunnis and Arabs know specific to themselves, Iranians and Shia were highly involved in them and those which Shia don't consider is the historical memory of the majority of Islamic world. This historical memory is the distinction aspect of Islamic world with West civilization.

\section{Historical memory of Islamic world}

The understanding of Muslims from their relation with west is obviously based on two general subjects: The decline of long-term agreement of Islamic civilization, and the deep feelings of Muslims that they are surrounded by the west. Muslims are well aware of the end of their military, technological, scientific and cultural superiority in a millennium that ended in the renaissance. It was the era which after that the fall of Muslims and the rise of Europeans started. If Muslims are in sorrow because of the loss of their splendor and glory, power, and their influence, they have also suffered from the west civilization that ended their superiority ${ }^{5}$. History readings of Muslims are in fact their psychological, cultural, and historical view to the contemporary history. It is possible that Muslims hide their feelings toward the historical occurrences in their interactions with the west; however, these considerations still exist in their collective thoughts (Fuller and Leser, 1995: 51). In investigation of history, it should be kept in mind that history, culturally, is highly beyond recording of events. As contemporary humans re-investigate their political and cultural heritage, new aspects of the past may become important and they reveal new viewpoint that might not have existed at that time; also, humans rewrite history based on their own needs and understandings (R.K. Kheirandish, 1388: 6). This is why today, Islamist activists delve into the history of Islam so that they can re-find raw materials, political cases, and ideologies that are helpful for the contemporary politics (Fuller and Leser, 1995: 52).

\section{Crusade wars}

Muslims have considered the west as their historical enemy and also they consider confronting with the west as one their highly important goals. This viewpoint is backed up by a history rife with conflicts of Muslims with Europe. These conflicts started from the era of holy prophet Muhammad in confronting Byzantium and reached to Syria, Egypt, Sicily, Andalusia, France, and some parts of Italy, in the era of caliphs after him. However, the peak of these conflicts happened while Europe attempted to retake their lost heritage. The bicentenary attacks of crusade knights to holy lands of Muslims and their horrible crimes $^{6}$ are of the most important reactions of Europeans against Islamic government. Muslims were acquainted with Europe; however, it was the civilized parts -Byzantium Empire- that were compatible with governments of Middle East rather than Frank and Norman governments of medieval. Confronting with the medieval layers of Europe was very painful for Muslims as eastern coasts of Mediterranean to the proximity of Egypt and north of Iraq were fallen to the hands of their enemy. More importantly, Jerusalem was their center and even there was a time when they were determined to occupy Mecca and Medina in order to free Jerusalem from Muslims. Gradually, Muslims were successful in defeating the

\footnotetext{
${ }^{5}$ For more information R.K. (Chamberlin, 2007)

${ }^{6}$ The crimes of crusaders in Antioch, Macarah, and Jerusalem stunned Muslims. For more information R.K. (Maalouf, 1364) 
crusade governor of Jerusalem and establish Muslims' government over there. However, thereafter, the crusade wars turned into the most important emotional occurrence for Muslims that not only was indicator of physical occupancy, but also it was the indicator of establishment of a Christian country in the heart of Islamic countries. In retrospect, today, the background of imperialism and colonialism aspects of the west is evaluated and in the viewpoint of Muslims, this background is connected with the establishment of a Jewish country in Palestine in 1948. Today, Islamists view the issue of crusade wars with the aspect of conflicts between Christianity and Islam (Haman: 54) in which the issue of Palestine and Israel is the new aspect of crusade wars in civilizational confrontations ${ }^{7}$.

\section{The necessity of paying attention to history of Islam by the media of Iran}

The Islamic republic of Iran, as the biggest government which is opposed to America (United States) and the west in Islamic world, claims the unity of Islamic world against the west. The Islamic Republic of Iran has done a lot of attempts to make Islamic countries accompany this thought. Although the heads of the Islamic countries have not totally accompanied Iran because of numerous reasons such as their unions with the US and west countries; however, Iran's investment on poor people of Islamic countries has caused the affability of the hearts of Muslims. Meanwhile, the presence of Iranian media supports this union; but, this union is in danger by rival media. First, beside Iran's Arabic language media, there are many Saudi Arabic language media and their political affiliation based on Arabic identity attempt to confront the software policies of the Islamic Republic. Second, western media and their attempt to deface Iran and values of Islamic Republic has caused a considerable number of assaults to Islamic countries so that, in this way, not only can they be able to take the leadership of Islamic world from Iran, but also, they can find a better alternative for it. However, a part of this strong performance is related to Iranian's crossborder media.

\section{Introducing the proceedings as anti-crusades}

Iran, as the supporter of the poor in the world -in general, oppression of Islamic world against the west- is the forefront of the fight against Zionists. Political-Military action of Iran has made this issue clear; however, the News coverage of Saudi and western media, present these activities as the attempts to destabilize the Islamic world and development of terrorism ${ }^{8}$. Not relying of Iran on historical memory of crusades and Muslims' anti-crusade spirit, has caused that despite the excessive costs of confronting Israel, vast majority of Sunni followers set eyes on Islamic fundamentalist groups such as Al-Qaeda, and ISIS, as the forefront of fight against the crusades; although, in reality no confrontations against Israel is observed. However, the attempts of their media, by relying on the collective memory of Islamic world, have made this mentality. Dealing with history in Iran is considered as minimum readings due to special tendency towards tyranny and idols. This issue has caused Islamic Republic to be far away from the deep identity of a great majority of Islamic world.

\section{Paying attention to the history of middle ages}

The middle ages of Iran history, despite the prevailing dominance of Sunni, has left a great deal of cultural, political, military, religious, and civilizational achievements. A side from the growing of the Islamic world's great thinkers and scientists at this point, the expansion of Islamic empire relying on Iranian heritage was the most important political-military achievement. During Seljuk era, Iranian rulers have caused the greatest defeat of Roman government ${ }^{9}$ in Malazgerd battle. Not paying attention to military development of governments of Iran in Middle Ages has caused the governments of Turkey to record these honors by its Iranian documents in Islamic world and to recognize the great Seljuk Empire as its own heritage.

\footnotetext{
${ }^{7}$ For more information R.K. (Ohana, 2011)

${ }^{8}$ This is while the most important characteristic of Saud and west based terrorism is connecting violence with media and release of its news. For more information see R.K. (Munkler, 1384: 247)

${ }^{9}$ Byzantium

Submit Date: 01.05.2016, Acceptance Date: 20.06.2016, DOI NO: 10.7456/1060JSE/082 Copyright (C) The Turkish Online Journal of Design, Art and Communication
} 
By the beginning of the crusade wars, Iranians had an important role against the crusaders. First, it should be considered that the attack of crusaders to the eastern shores of the Mediterranean was the attack to the territory of the Seljuks. Besides, the capital of Seljuk territory was Isfahan; therefore, this attack was considered as an attack to Iran lands. Second, the first people who stood against crusaders and founded Ghazi states were from Iran. Atabakan-E-Zangi government, the first and the most honorable Islamic government, used Iranian heritage in the administration of the country to stand against crusaders (Mohsen Hossein, 2003: 38 and 41, Ebadi, Bi Ta: 36). An important part of the army was Iranian soldiers (Ghazvini and Tatavi, 1382:2523/4). Persian language had an important position in their government (Safari Agh Ghale, 1389: 7) and basically, this government was a branch of Seljuk with the centrality of Isfahan and Khorasan (Ibn Emrani, 2001: 216. Ibn-E-Athir, Bi Ta: 29). Ayoubian government was raised by Zangian (Ibn-E-Shadad, 1994: 72) and it was based on Iran's Kurds and it almost saved Iranian administrative heritage. Also, after Ayoubian, the owned empire, by attracting Kharazmshahian soldiers, was able to confront Mongols in Eyn-Al-Jalout and attack crusade lands ${ }^{10}$ (Meghrizi, 1997: 477/1).

\section{Presenting Iran's historical anti-crusader identity}

These cases and many other examples are all representatives of the significant role of Iran in confronting Crusades; however, unfortunately because of not paying attention of Iran to this historical identity, has left the arena open for the constructivist policies of the rival governments such as Turkey, Saudi Arabia, and Iraq (Saddam era). Paying attention to this history will inform the minds of the Islamic world of military actions of Iran against crusades and accompany the current action of Iran against Israel with a historical memory. This process, in the times of crisis such as 33-day and 22-day wars, will be more effective than before, which its necessity is the strong support of media and giving direction to historical memory of Islamic world for achieving the goals of Islamic Republic. In this process, Iranian identity along with huge identity of Islamic world, introduces itself as a Muslim who has a serious and important borders with the west. Not a Rafidah identity which intends to disturb the order of Islamic world and increase terrorism. At the moment, the emphasis on prophet Muhammad and Imam Ali era, and Shia uprising are most of the productions of Iran's media that represent Shia identity, not the Islamic identity. In this production, "the other" is the Umayyad or other Islamic caliphs, not a ruler or non-Muslim person. These productions reinforce the smaller Shia identity, not the huge Islamic identity. Therefore, the identity feed for the Islamic world should be considered along with the media productions for Shia identity in which "other" be the west, not another Muslim. The historical capacity of Iran in confrontation with the western world from ancient times and all over the Middle Ages is very high. Declaring this historical heritage and relying on it for legitimating the current political and military action can be very helpful in advancement of Islamic Republic for uniting the Islamic unity along with its goals. This historical identity that is based on past glories, on the one side, brings unity for the groups concurring with Iran, and on the other side, strengthens the will. Skiles states the following about the future wars:

"The number one advantage in the future is that we should be able to break the enemies' will -it means that we should be to destroy the morale of enemies" people" (Skiles, 2001: 153).

This issue, in addition to military forces, is mostly relied on psychological missions and media activities. Relying on the triumphantly historical background against the west, makes higher self-confidence in Islamic world towards the actions against the west and the proceedings of Islamic republic will be shown more Jihadi and successful in the Muslims' viewpoint; because, this documentations have roots in their historical identity. The victories of the 33-day and 22-day wars of Lebanon and Palestine, with the help of

\footnotetext{
${ }^{10}$ According to historical narrations, Saif ad-Din Qutuz was the nephew of Sultan Jalal al-Din Khwarazmshah Submit Date: 01.05.2016, Acceptance Date: 20.06.2016, DOI NO: 10.7456/1060JSE/082 Copyright (C) The Turkish Online Journal of Design, Art and Communication
} 


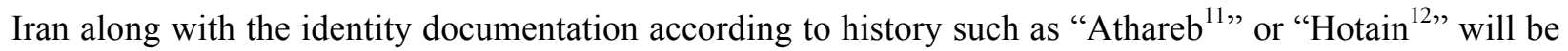
very effective.

\section{RESULTS}

Identity has two aspects: affirmative and negative. One aspect is looking forward to defining itself and the other aspect defines the "other". The difference between "self" and "Other" based on the range of the definition of identity can include a small or large area. Currently, the largest layer of identity is civilization identity that forms the current boundaries in the world. The ability to make the identities for other countries accompany with political objectives, is one of the aspects of influencing and achieving goals that is addressed in constructivism theory. In fact, with this view, by the means of media tools, it is possible to make nations accompany, regardless of the directions of other governments and create an identity in accordance with the desirable goals with civilizational queuing outside the borders. The western civilization, as the super-power identity in the world, is considered as the greatest rival of the identity of the Islamic civilization. The confrontation of the Muslims with the west is almost due to their historical memory. The violent and long-term conflicts between the Muslims and the European which was shown clearly in the form of the crusades have caused the "other" of Islamic civilization to be westcrusade enemy. Although this historical memory is common among the Muslims, but the religious and tribal minor identities are considered as the most important cause the segregation of identity. The Islamic Republic of Iran, as the most important power of Islamic world against the Western civilization, has had the most conflicts with Israel in recent years and it can take advantage this conflict for recruiting from the members of Islamic identity against the west. In Muslims' historical memory, the Zionist regiment is exactly located on a place which their crusade successor turned to seizure of Islamic lands. The advertising gap of the Islamic Republic of Iran in introducing its attempts as the fight against the crusaders has made the Islamic Republic not to be able to rely on the deep roots of identity of the Islamic world and hence, it is considered as an offender by its opposing powers such as Saud and its companions. However, considering the actions of Iranians in history, especially, confronting with crusades have taken the monopoly of the historical fight against the west from Arabic countries and Turkey and have made it possible to establish a firm base in the minds of the Muslims of the world by using the historical identity of Muslims and to be almost able to rely on the Islamic nations in confronting Israel.

\section{REFERENCES}

1. Ibn al-Athir Jersey, M. Brilliant history in the state Attabaki Mosul, Cairo: Daralktb Alhdysh.

2. Bull, M. and Hously, N. (2003) the experience of crusading, Cambridge: Cambridge University press.

3. Chamberlin, J. M. (2007). Imaging Defeat: an Arabic Historiography of the Crusaders, Monterey, California: California university press.

4. Fuller, Graham E. and Lesser, Ian O. (1995)A Sense of Siege: The Geopolitics of Islam and the West, Colorado, Westview Press.

5. Huntington, Samuel P.(2004)Who are We?: The Challenges to America's National Identity, new York, Simon \& Schuster.

\footnotetext{
${ }^{11}$ In 524, Imad-e-Din, was able to defeat the crusades of the north badly and eradicate a large number of their troops. Ibn-e-Athir state: "One night in $584 \mathrm{AH}$, I was passing that land, as the locals told me, many of the foreigners' bones were around that part until that time" (Ibn-e-Athir, 1371: 140/25)

${ }^{12}$ A great battle in which the Ayyoubi army was able to defeat the troops of Jerusalem crusaders and killed and captivated a large number of them. After this battle, Jerusalem was returned to Muslims (Ibne-Athir, 1371: 89/29)
} 
6. Jepperson, Ronald L., Alexander Wendt, and Peter Katzenstein. (1996). "Norms, Identity, and Culture in National Security, new York, Columbia University press.

7. Ohana, D.(2011), Israel and Its Mediterranean Identity, London: Palgrave Macmillan

8. Price R. M. and Reus-Smit c.(1998)dangerous liaisons? Critical international theory and constructivism, European international relation. 4,3

9. Scales, Robert H.(2001)Future Warfare Anthology, Pennsylvania, U.S. army war college.

10. Turner, J. H. (2001), Handbook of Sociological Theory, California: California University press.

11. www.oxforddictionaries.com Oxford Dictionary, "Identity" 